\title{
ARTE RELIGIOSO ESPAÑOL DEL SIGLO XX: PICASSO, GUTIÉRREZ SOLANA Y DALÍ
}

\author{
POR \\ J. M. BLÁZQUEZ \\ Real Academia de la Historia
}

\begin{abstract}
Picasso until the year 1959 painted frecuently themes religions, mainly crucifixions. The painting of Guernica is based to a crucifixion from 1932. He used the crucifixion to simbolize the brutality of the modern world. Solana painted very often processions from the country-folk and also scenes from the death. Dalí was very late interested in his artistic works about religion themes, but from 1946 there were very frecuently and assorted.
\end{abstract}

El tema religioso no ha sido ajeno a los grandes pintores españoles del siglo xx, aunque dicho aspecto del arte español de este siglo permanece sin estudiar. En este trabajo solamente pretendemos estudiar las aportaciones hechas en tal sentido por los tres grandes maestros españoles indicados en el título, y de algún otro.

\section{Picasso}

El gran coloso del arte pictórico del siglo xx no podía estar ausente de la lista de artistas españoles que abordaron motivos religiosos, aunque no destacó - al menos públicamente- por sus sentimientos religiosos; al contrario, se le tiene como persona y autor "profano", en el sentido antirreligioso del término.

Empezó su carrera artística con algunas composiciones religiosas, de las que recordamos algunas, como La primera comunión, óleo sobre lienzo datado en $1896^{1}$, y Ciencia y Caridad, de

1 Carsten-Peter-Warncke, Pablo Picasso 1881-1973, Bonn 1991, pp. 38, 47-48; J. A. Gaya Nuño, Picasso, Madrid, 1957, pp. 33-34; J. Richardson, Una biografía, I. 1881-1907, Madrid, 1995, pp. 81-87, de Picasso. Hay otros temas religiosos: La aparición de Cristo a Santa Margarita María de Alecoque, 1896; Asunción, boceto para un cuadro de altar; y Escena bíblica; todos del mismo año; y Descanso durante la huida a Egipto, 1895 (J. A. Gaya Nuño, op. cit., p. 126). P. Cabanne, El siglo de Picasso, I. El nacimiento del Cubismo. Las metamorfosis (1881-1933), Madrid, 1982, pp. 50-53. Sobre los años de aprendizaje del pintor: C. P. Warncke, Pablo Picasso 1881-1973, Colonia 1992, pp. 38-39; J. Barroso, «Religiosidad y vanguardia española, una asignatura pendiente" Actas del X Congreso del CEHA. Los Clasicismos en el Arte Español, Madrid, 1994, pp. 91-93. 
1897, también óleo sobre lienzo ${ }^{2}$, dos obras sugeridas por su padre. En la primera de ellas representa a una muchacha toda vestida de blanco que reza arrodillada ante el altar, acompañada de sus padres, en presencia de un monaguillo que la contempla ensimismado. Contrasta el tono oscuro del fondo y de los vestidos de las paredes con el traje de la joven, del monaguillo y de los corporales del altar. En el segundo cuadro ya se barrunta la gran calidad artística del joven pintor, sobre todo en el tratamiento de las ropas, en los brazos de la monja de la Caridad, en la sábana del enfermo, en la colcha, y en la actitud pensativa del médico que toma el pulso a la enferma. El modelo del doctor fue su padre. Hay un contraste grande de colores, dominando los tonos oscuros, pero no los grisáceos del cuadro anterior. Estos dos óleos son importantes por pertenecer a la etapa de aprendizaje del pintor, entre 1890 y 1898.

En el denominado Periodo Azul, que abarca los años 1901-1904, Picasso pintó tres cuadros de algún modo relacionados con lo religioso. Dos de ellos son La Cabeza entre la ropa y La muerte de Casagemas, obra del verano de 1901. En el primero, óleo sobre madera, está magníficamente tratado el color amarillento sobre el rostro enjuto del difunto, junto a la luz de una vela de tonos suaves. El tercer cuadro, óleo sobre lienzo, titulado El entierro de Casagemas ${ }^{3}$, domina el color azul en toda la composición. Está magníficamente expresado el dolor de los asistentes al sepelio y de las parejas situadas en el Más Allá en el viaje a la ultratumba, dentro de nubarrones azulados.

En los otros periodos de producción artística de Picasso, el Periodo Rosa (1904-1906), seguido de la etapa de las esculturas de influencia africana o ibera (1906-1907, el Cubismo Sintético (1912-1915), el Clasicismo (1916-1924), utilizando la clasificación de Carsten - Peter Warncke, está ausente la temática religiosa en la obra del pintor malagueño. Hay que esperar a 1930 para encontrar de nuevo motivos religiosos en su pintura al óleo. En los trabajos de esta época se reflejan magníficamente las tensiones originadas por la aflicción y la violencia del momento presente.

El tema de la Crucifixión de Cristo encaja perfectamente en esta tendencia. La composición aparece con numerosas variaciones. Algunas fueron inspiradas en la Crucifixión de Grünewald del altar de Isenheim. Fueron obras realizadas en 1932, con la técnica de pluma y media aguada. Sin embargo, la primera obra de esta serie es un óleo sobre contrachapado, de 1930, que se caracteriza por los colores vivos, por el desgarro de los gestos en las figuras de Cristo y de los asistentes ${ }^{4}$. En este sentido, los artistas pre-renacentistas, y también del Renacimiento, son los que mejor expresaron la brutalidad del suplicio de Crucifixión, dolor que se reflejaba también en los rostros de los asistentes: así lo vemos en las Crucifixiones de los Maestros de Viena, 1325 (dos); de Bohemia, 1350; de Wittingau; de Santa Verónica; de Conrado von Soestz; de H. Pleyden Wurff; de Lucas Cranach; y de Hausbuchesi, todos artistas germanos; pero también de R. van der Weyden y de E. Garton, 1460; y de italianos como S. Boticelli hacia 1490. Por su parte, los

2 Carsten-Peter-Warncke, Op. cit., pp. 47-48, 50-51; R. Penrose, Picasso. Su vida y su obra, Barcelona, 1981, pp. 3739; C. P. Warncke, Op. cit., pp. 50-51.

3 Carsten-Peter-Warncke, Op. cit., pp. 86-87. C. P. Warncke, Op. cit., pp. 86-87; P. Daix, Picasso 1900-1906. Catalogue raissonné de l'oeuvre peint, Neuchâtel, 1966, pp. 192-194; Th. Reff, Picasso 1881-1973, Barcelona, 1984, pp. 11-48, sobre el tema del amor y la muerte en las obras juveniles de Picasso. En 1908 pintó un San Antonio y Arlequín. En 1899 1900 se fecha un dibujo de tres Moribundos en un hospital debajo de un crucifijo; P. Daix, Op. cit., p. 19, Fieles delante de una iglesia, de 1901.

4 Carsten-Peter-Warncke, Op. cit., pp. 337-369; R. Penrose, Op. cit., pp. 227-231; R. Langley. Picasso, Madrid, 1991, pp. 116-117; C. P. Warncke, Op. cit., p. 336; P. Cabanne, Op. cit., pp. 419-421. Testimonio a favor del interés de Picasso por Dios. Diferentes cuadros de Crucifixiones de artistas del Renacimiento: A. Stange, Altdeutsche Malerei, Colonia, sin año, láms. 42-43, 46, 56, 64, 67, 101; M. Wundram, Malerei der Renaissance, Colonia, 1997, pp. 57, 69, 111, 120. Las Crucifixiones de Durero son de gran realismo. Ver también: D. Kurschbach, Albrecht Dürer. Die Altäre, Stuttgart, 1955 , láms. 72, 77- 78 . 
Cristos pintados por los grandes artistas españoles de los siglos XVI, XVII y XVIII expresan muy bien el dolor, si bien éste no es tan desgarrado como en los artistas del Renacimiento italiano o flamenco, y trasmite mayor grado de resignación ante el suplicio de la cruz. Recordamos varios Cristos debidos al Greco y a su taller en torno a 1580, en 1585-1590, 1600-1606 (tres), 1605 1610 (dos), 1610-1615. Del taller del Greco (Jorge Manuel), 1610-1614 (dos), o los Cristos obra de Zurbarán, Velázquez o Goya.

Los cuerpos crucificados en el arte moderno han merecido dos exposiciones celebradas una en el Museo Picasso de París, entre los meses de noviembre 1992 y marzo de 1993; y una segunda en el Musée des Beaux-Arts de Montreal, en los meses de marzo, abril y mayo de ese mismo año. Con motivo de tales muestras fue publicado un catálogo donde se pasaba revista a la Crucifixión como tema iconográfico en el arte reciente: en la obra de Picasso, de Bacon, de Dis, de De Kooning, de Guttuso, de Sutherland, de Saura, a los que se podrían añadir otros pintores del siglo xx a los que luego haremos referencia ${ }^{5}$.

Picasso había sentido a lo largo de su vida un interés - a veces larvado y a veces manifiestopor la Crucifixión como tema pictórico, del que han quedado ejemplos: un dibujo de mina de plomo sobre papel, de $1892^{6}$, un Cristo crucificado, de 1896, óleo sobre lienzo, de fondo oscuro, sobre el que resalta, claramente inspirado en el de Velázquez ${ }^{7}$; Cristo delante de Pilatos, de $1896^{8}$, pluma en color bruñido, donde cuatro figuras aparecen apenas esbozadas, aunque las personas que participan en el juicio están más trabajadas; y la dama vestida de luto arrodillada ante un crucifijo, junto a la cabecera de la cama donde yace un niño enfermo, realizado a lápiz negro en $18999^{9}$. En 1901 realiza tres dibujos con el tema de la Crucifixión de Cristo; uno de ellos en tinta china y pastel. El pintor, en la misma hoja añade una serie de estudios: en el ángulo superior izquierdo colocó una cabeza de Cristo, de pequeño tamaño, de aspecto macilento, acompañado de una figura de vieja sentada, de color rosa, e intenso sombreado a sus espaldas, una cabeza de dama de perfil y una mano sosteniendo un pincel ${ }^{10}$.

En una Crucifixión, que se fecha en 1902, Cristo tiene un cuerpo alargado y estrecho, suspendido en el aire, sin cruz, hecho en mina de plomo ${ }^{11}$, de un estilo totalmente distinto al Cristo Crucificado en el que había seguido la obra de Velázquez. Al año siguiente, también con la técnica de mina de plomo realiza otra Crucifixión, muy parecida a la anterior ${ }^{12}$. La cabeza de Cristo, caída, muestra deliberadamente el mismo estilo que las cabezas de las figuras que acompañan al crucificado. Habrían de pasar algunos años para encontrar de nuevo una Crucifixión ejecutada en mina de plomo, hacia 1915-1918 ${ }^{13}$, y en tinta china. Este dibujo significa un cambio radical a las anteriores representaciones del crucificado en el arte de Picasso. El artista representa magníficamente el dolor del moribundo: la boca entreabierta por la asfixia, los ojos transidos, la cabeza ladeada hacia el cielo, los dedos de las manos agarrotados y tensos que intentan cerrarse. El cuerpo de Cristo muestra una musculatura fuerte de brazos y tórax, que recalcan el dolor del suplicio. Picasso realiza en 1917 en tres dibujos con el tema de la Crucifixión, que suponen una evolución en su arte: las figuras son cuadradas y están amontonadas unas sobre otras ${ }^{14}$.

Una de las Crucifixiones picassianas más famosas es la pintada al óleo en 1930, hoy en el

\footnotetext{
5 Catálogo Corps crucifiés, París, 1992, Picasso. Bacon. Dix. De Kooning. Guttuso. Sutherland. Saura.

6 Catálogo Corps crucifiés, pp. 14, 145, n. 4.

7 Catálogo Corps crucifiés, pp. 15, 145 n. 6.

8 Catálogo Corps crucifiés, pp. 16, 145, n. 5.

9 Catálogo Corps crucifiés, pp. 16, 145, n. 7.

10 Catálogo Corps crucifiés, pp. 17, 148, n. 8.

11 Catálogo Corps crucifiés, pp. 18, 145, n. 9.

12 Catálogo Corps crucifiés, pp. 19, 145, n. 10

13 Catálogo Corps crucifiés, pp. 20, 146, n. 11.

14 Catálogo Corps crucifiés, pp. 21-23, 146, n. $.^{\text {ss }} 12-14$.
} 
Museo Picasso de París (Fig. 1). El cuadro ha sido bien estudiado por R. Kaufmann 15, el cual propone tesis interpretativas muy distintas a las vigentes sobre esta obra clave en la trayectoria artística del pintor. De un año antes datan dos minas de plomo de una gran originalidad en la disposición de las figuras, que se adelantan al óleo de $1930{ }^{16}$. Se caracteriza el óleo de Picasso por la intensidad y contraste de sus colores, por el número de figuras y por la violencia expresada. Este óleo prefigura ya el Guernica, obra de 1937. De ahí su importancia, en opinión de A.H. Barr, R. Penrose, W. S. Rubin, E. Elsen, y A. Blunt. Ha sido considerada una obra enigmática. El centro de la composición lo ocupa la figura de Cristo crucificado entre dos cruces, el centurión a caballo atravesándole el costado con la lanza, un soldado encaramado en una escalera martilleando un clavo en la mano del crucificado, y dos soldados jugándose a los dados la túnica de Cristo. R. Kaufmann precisa que «el mundo real ha constituido el punto de partida de la Crucifixión, el mundo real de las reliquias y de las formas del arte primitivo estudiadas por los autores surrealistas. En efecto, la actitud de Picasso, en la Crucifixión, parece ser la de un psiquiatra-antropólogo examinando fríamente el comportamiento humano».

En esta Crucifixión la identificación de este suplicio como ritual primitivo se vuelve más patente. La crucifixión la practicaban ya los asirios y los fenicios, quienes la extendieron por la toda cuenca del Mediterráneo. Los romanos la convirtieron en un tormento para los esclavos y criminales. La cabeza y el cuello de Cristo, en este caso, recuerdan las figuras de arte cicládico, parentesco que otorga a esta composición un carácter primitivo, reforzada esta identificación por las imágenes del sol y de la luna colocada a la derecha de Cristo. La imagen del sol puede ser una referencia al dios Mithra, de origen iranio, cuyo culto compitió ferozmente contra el cristianismo en el Imperio Romano. La presencia de los astros indican posiblemente que para Picasso la Crucifixión es un ejemplo de sacrificio primordial. Picasso colocó junto a la figura de Cristo los símbolos de la religión primitiva. R. Kaufmann ${ }^{17}$ cree que el influjo de un artículo de Baille -publicado en Documents 3,1930-dedicado a Picasso, inspiró en este punto al pintor malagueño. La actitud ritualista de la figura situada a la derecha del sol-luna, en un contexto surrealista, legitima la hipótesis de que esta figura se sitúa al mismo nivel que la del Crucificado, y las imágenes del sol-luna representan una actitud ritual. Según R. Kaufmann, "constituiría de este modo el tercer elemento de un muy coherente triunvirato iconográfico de figuras generalizadas de culto. Al contrario desde un punto de vista puramente formal, tres imágenes, al revés de las otras figuras del cuadro, todas colocadas de perfil, están unidas por la analogía de su posición, simetría y frontalidad. La frontalidad y la simetría de estas figuras parecen indicar una significación hierática».

Como indica R. Kaufmann, Picasso añadiendo un grupo de figuras angustiadas y deshumanizadas, próximas al triunvirato de los ídolos, participa del interés de los surrealistas por los ritos primitivos como medio de exploración del espíritu irracional del ser humano. Todas estas figuras pertenecen a su propia representación de lo irracional: la Magdalena, que mejor podría ser identificada con la virgen María por su semejanza con una figura femenina en un dibujo de la Crucifixión de 1938, que va unida a Cristo por un cordón umbilical, con la boca bien abierta, con los dientes bien señalados, y con el brazo en alto. El brazo se sitúa próximo a una cabeza de mantis religiosa, especie de insectos cuya hembra devora al macho tras realizar el acto sexual. Este insecto se encuentra ya en cuadros realizados en los meses anteriores a la Crucifixión. La connotación sexual, manifestada claramente en las primeras Crucifixiones, reaparece en este cua-

15 La crucifixión de Picasso, de 1930; Catálogo Corps crucifiés, pp. 74-81, fig. 1; G. A. Gaya Nuño, Op. cit., pp. 126127; W. Rubin, Pablo Picasso. A Retrospective, Nueva York, 1972, pp. 278; R. Penrose, Op. cit., pp. 184-185, 187, 193; con los dos Estudios para una Crucifixión, La Crucifixión de 1930 y dos Crucifixiones de 1959.

16 R. Kaufmann, Op. cit., p. 79; Catálogo Corps crucifiés, pp. 24, 145-146.

17 Op. cit., pp. 78-79. 
dro, pero acrecentada debido a la desvalorización de la imagen de la Magdalena, que aparece como infrahumana, igual que los dos soldados que sortean la túnica, con cabezas de pájaros; uno de ellos (a la izquierda de la escalera) tiene una cabeza monstruosa. El centurión y el hombre encaramado en la escalera están representados en tamaño diminuto, y son pruebas del interés de Picasso por la Crucifixión como medio de indagar en la raíces del sadismo y de la brutalidad entre otras manifestaciones de la ferocidad humana. Las dos figuras situadas a los pies de la escalera se han interpretado unánimemente como los dos ladrones, ya crucificados y posteriormente descolgados de la cruz. Estas figuras están inspiradas en el Apocalipsis guardado en la abadía de Saint Sever, fechado en el siglo XI, dado a conocer por Georges Bataille en Documents de 1929. Picasso se sintió influenciado una vez más por las figuras de una religiosidad primitiva, en este caso el cristianismo.

La imagen colocada en el plano superior, en el lado izquierdo, encima del pájaro, se ha interpretado generalmente como una esponja de vinagre en tamaño gigantesco. R. Kaufmann opina que también podría estar tomado de la escena del Sueño de Nabucodonosor en el citado Apocalipsis de Saint-Sever. Los colores empleados por Picasso en este cuadro son muy parecidos a los del citado manuscrito y son típicamente españoles.

La Crucifixión de Picasso del año 1930 no es, pues, una obra enigmática, como se ha dicho. Encaja muy bien, como argumenta R. Kaufmann, «en el contexto del interés de los surrealistas por las prácticas religiosas y por las formas del arte primitivo estudiadas en tanto que manifestaciones de la naturaleza irracional del hombre».

Picasso en 1932 realizó trece diseños ${ }^{18}$ (Figs. 2-4), en tinta china, inspirados en la célebre Crucifixión de Mathias Grünewald ${ }^{19}$, que parecen indicar un interés por la invención puramente plástica. Los artistas españoles realizaron algunos Cristos de gran calidad, como los famosos de la escuela sevillana.

Picasso estableció, según R. Kaufmann, una relación entre la figura de Cristo y la del gallo destinado al sacrificio. En ese mismo año se había interesado por la mitología y por lo imaginario, que plasma en escenas del Minotauro y de la tauromaquia ${ }^{20}$, en las que aparece a menudo un hombre con los brazos abiertos en cruz (Fig. 5) que en seguida recuerdan al Crucificado. En todas las obras alegóricas de Picasso de esta época, incluido el Guernica, se repiten los motivos de la Crucifixión, lo que confiere una enorme importancia a la Crucifixión de 1930. Concluye R. Kaufmann su excelente estudio afirmando que «Picasso ha cogido los motivos de los antiguos ritos de la Crucifixión, del mitraísmo y de la corrida, para representar la situación moderna del bombardeo de una población civil... En la Crucifixión y en el Guernica Picasso aborda el mismo tema: el de la irracionalidad humana bajo la forma de la histeria, de la brutalidad y del sadismon.

Picasso todavía volvió al motivo de la Crucifixión en años posteriores, con una Crucifixión realizada en 1938, en técnica de pluma y tinta china ${ }^{21}$. Realiza un Cristo con la cruz a cuesta en 1951, inspirado en el retablo de Saint-Thomas de Francke ${ }^{22}$, y en 1959 una Cabeza de Cristo ${ }^{23}$.

\footnotetext{
18 Catálogo Corps crucifiés, pp. 25-29, 146, n. ${ }^{\text {ss }}$ 17-29; G. Bouldaille, Picasso. Dibujos, París, 1986, p. 75; W. Rubin, Op. cit., pp. 300-301; las trece Crucifixiones de 1932.

${ }_{19} \mathrm{Ch}$. Heck. «Entre le mythe et le modéle formel. Le crucifixion de Grünewald et l'art du XX siècle», en Catálogo Corps crucifiés, pp. 34-107.

${ }^{20}$ Catálogo Corps crucifiés, p. 146, fig. 35.

21 Catálogo Corps crucifiés, pp. 41, 147, fig. 33. Siguiendo la obra de Lucas Cranach, entre 1947 y 1949 Picasso hizo once diseños a pluma sobre plancha de zinc de un tema bíblico, David y Betsabé (ver: F. Mourlot, Picasso Lithographe, París, 1970, pp. 79-84, fig. 109).

22 Catálogo Corps crucifiés, pp. 40, 146, fig. 34.

23 J. Clair, Cette chose admirable, Le péché..., Catálogo Corps crucifiés, pp. 62-63, fig. 2.
} 


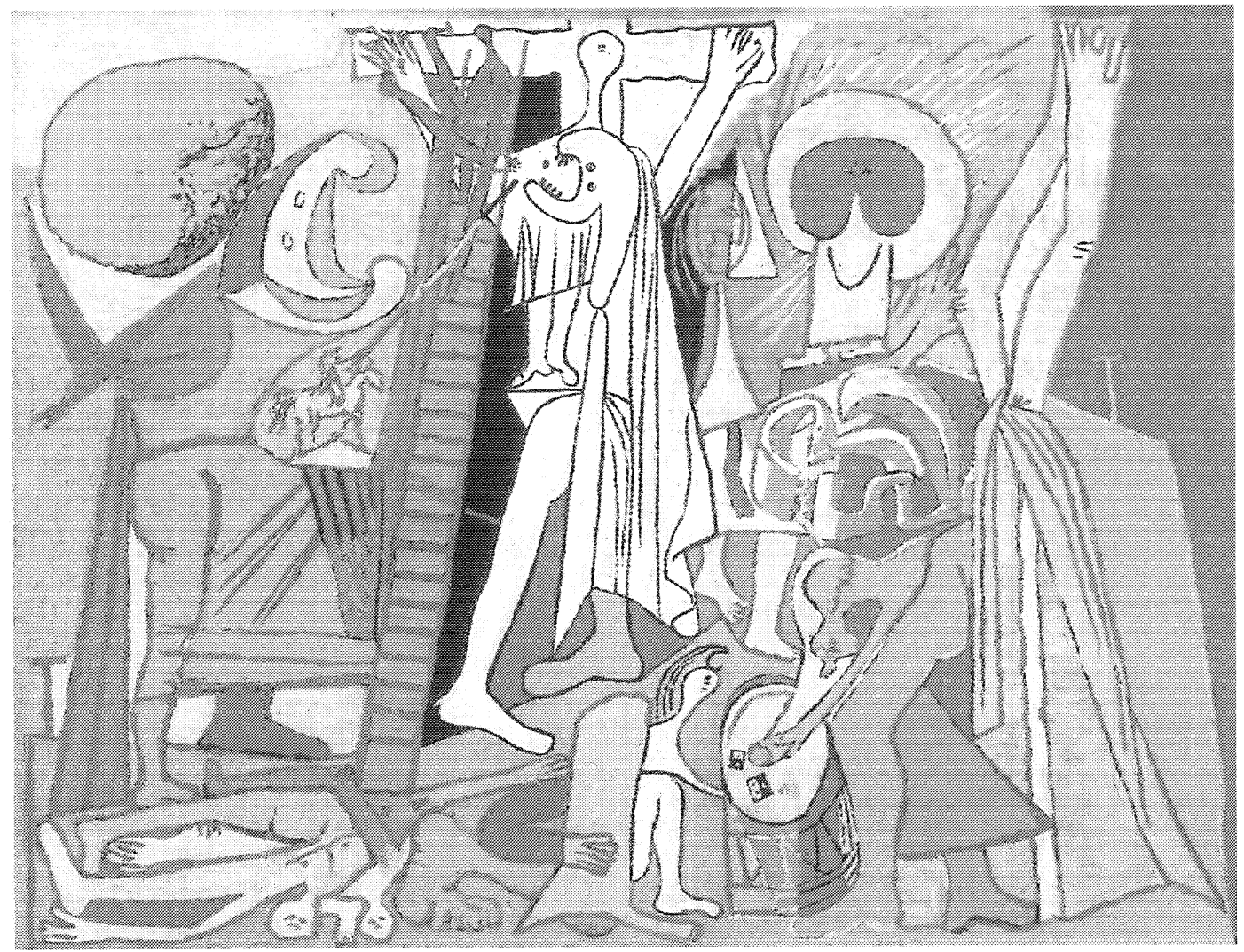

1
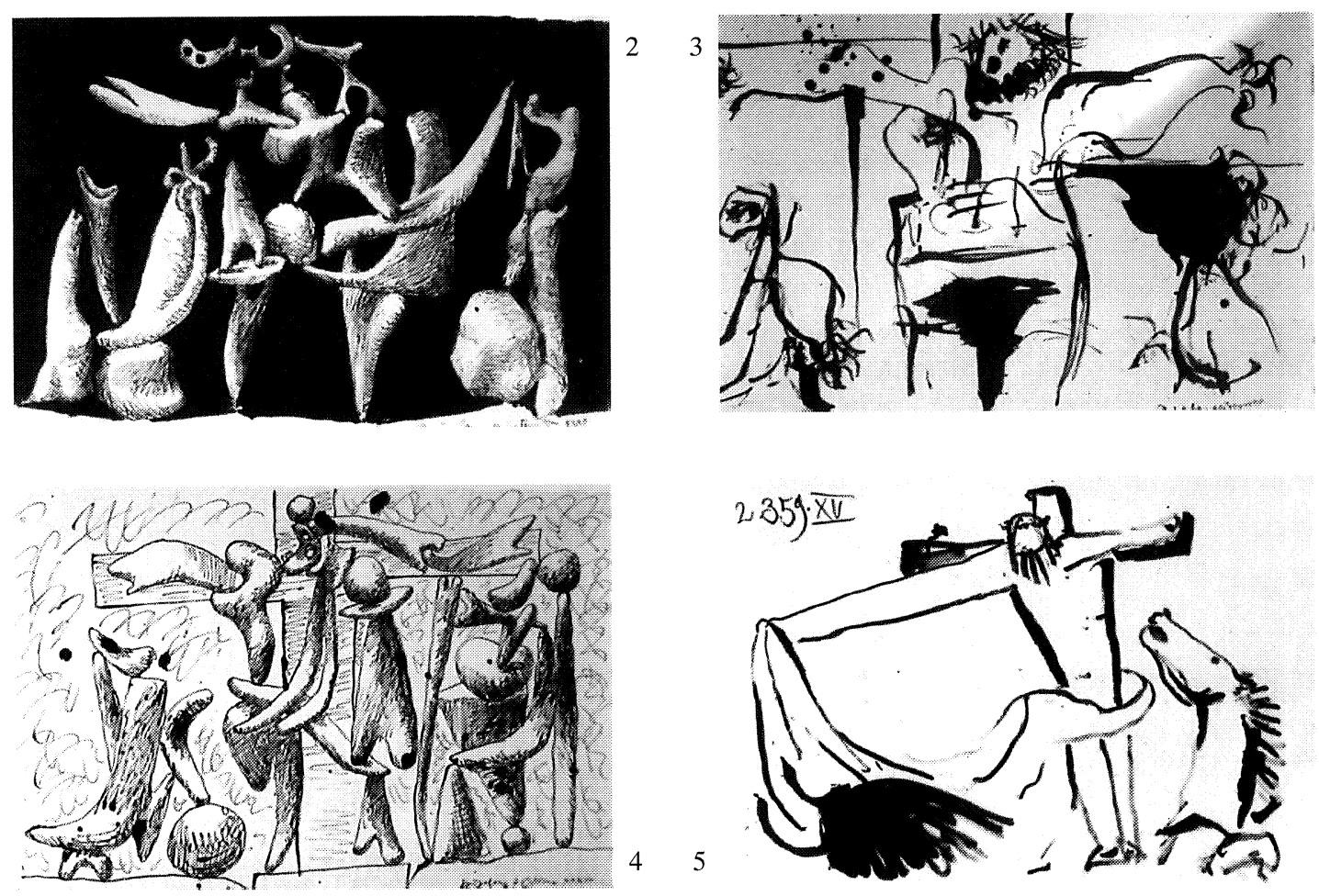

Fig. 1. Picasso, Crucifixión, 1930. París, Museo Picasso.

Fig. 2. Picasso, La Crucifixión, 1932. París, Museo Picasso.

Fig. 3. Picasso, La Crucifixión, 1932. París, Museo Picasso.

Fig. 4. Picasso, Crucifixión, 1932. París, Museo Picasso.

Fig. 5. Picasso, Toros y toreros, 1959. París, Museo Picasso. 


\section{La Crucifixión en el arte europeo del siglo $x x$}

El tema de la Crucifixión ha tenido aceptación en el arte del siglo xx. La influencia de la obra de Picasso es clara no sólo en la elección del tema sino también en su tratamiento y en su significado. Los artistas contemporáneos toman la Crucifixión como paradigma de la brutalidad del hombre del siglo xx. Mencionamos algunos casos, por ejemplo Guttuso ${ }^{24}$, que realiza una Crucifixión en 1938-1939, a la que siguieron otras en 1940-1941, que son fiel expresión de la brutalidad de la guerra (la Guerra Civil Española, la Segunda Guerra Mundial, y el Holocausto judío).

Guttuso, pintor laico, explica con claridad su idea de arte religioso: «La religiosidad de una obra de arte no es el fruto de un sentimiento individual, ni de la sinceridad de la inspiración individual, sino de la participación en un concepción general del mundo, que se refleja en la obra de arte. La relación entre lo inmanente y lo trascendente, entre un mundo físico real y el mundo metafísico, debe necesariamente formar parte integrante de la vida y de los pensamientos de la mayor parte de la Humanidad. Sin ella la religiosidad no sabría traducirse en una obra de arte».

A Grahan Sutherland se deben varias Crucifixiones ${ }^{25}$ en 1946. Los efectos devastadores de la Segunda Guerra Mundial influyeron profundamente en el artista, muy en la línea de Grünewald, condicionaron sus tremendas Crucifixiones.

Francis Bacon ${ }^{26}$, pintor, según él mismo reconoce, muy dependiente de la obra de Picasso, realiza varias Crucifixiones, de las que él prefiere un estudio realizado en 1962, hoy en el Museo Guggenhein de Nueva York, que como indica J.Clan, que entrevistó al artista, es casi la masacre de un cuerpo retorcido por el dolor, la parte del esqueleto visible. Para Francis Bacon no hay nada más bárbaro que la Crucifixión. Por su parte, el artista norteamericano De Kooning ${ }^{27}$, dentro de una estructura tradicional de la composición y de la ejecución de músculos y tendones, atribuye a la imagen de Cristo una mirada diabólica, que interpela al espectador. La presencia de las mujeres dan a la escena un carácter sacrílego. La escena se sitúa en un contexto humano corriente.

\section{La Crucifixión en el arte español del siglo $X X$}

Los artistas españoles, del mismo modo que los europeos, muestran mucho interés por el tema de la Crucifixión en su obra pictórica. Veremos algunos de ellos.

Mencionamos en primer lugar a Antonio Saura, que ha pintado numerosas versiones de la Crucifixión desde $1957{ }^{28}$ (Fig. 6), aunque no sea el primero en cuya obra se rastrea la influencia de Grünewald, reconocida por la crítica, y aunque tal influencia no sea formal directa sino en la forma de expresar el sentimiento trágico. Las Crucifixiones de A. Saura se caracterizan por dos largos ejes perpendiculares sobre los que se convulsiona el cuerpo, y donde los brazos extendidos delimitan los límites del espacio, y las manos extendidas en señal de dolor extremo. El artista declaró que su preferencia por el tema de la Crucifixión no obedecía a motivaciones religiosas. En su infancia le impresionó la visión del Cristo de Velázquez, inmenso, terrible y pacífico.

${ }^{24}$ E. Crispoli, "Guttuso, Crucifixión", Catálogo Corps crucifiés, pp. 108-116, fig. 37; M. Chagall también ha utilizado el símbolo de la Crucifixión para simbolizar la brutalidad del mundo moderno: W. Haftman, Marc Chagall, Colonia, 1988, fig. 35, del año 1940; pp. 84-85, lám. 10, de 1912; pp. 118-119, lám. 27; lám. 39, obra de 1944.

25 G. Bruno, «L'Oeuvre de Graham Sutherland», Catálogo Corps crucifiés, pp. 117-125, fig. 40.

26 J. Clair, «Le pathos et la mort», Catálogo Corps crucifiés, pp. 132-144, figs. 38-39.

27 C. Stonleig, «Picasso, De Kooning. Un même goût pour le dessin» Catálogo Corps crucifiés, pp. 126-132, figs. 41-44.

28 Ch. Heck, Op. cit., pp. 7-98, fig. 45. 
Las misteriosas manos representadas en las cavernas paleolíticas se prolongan en las manos crispadas de los crucificados. La crispación presente en la obra de Grünewald, al contrario, evoca el Cristo y la agonía del universo convulsionado. Antonio Saura reconoce que, al revés de Velázquez, ha buscado crear una imagen convulsiva y hacer una protesta borrascosa. La presencia intemporal del sufrimiento humano está implícita en el crucificado, y el sentimiento religioso está relegado al olvido.

Ignacio Zuloaga es el pintor más representativo de la generación del 98. Pinto unos Flagelantes (Fig. 7); un Cristo de la Sangre, en 1911; y Cristo y la niña ${ }^{29}$. J. Barjola realizó varias Crucifixiones en los años 1975, 1985, 1986 y 1987, de gran realismo.

Uno de los Cristos más famosos es obra de Gregorio Prieto, de un realismo anatómico perfecto, copiados al parecer de modelos vivos drogados. Sobre este artista volveremos en otra ocasión.

El tema de la Crucifixión se mantiene hasta la actualidad. En 1997 Chillida acaba de entregar una escultura de un Cristo para la catedral de San Sebastián.

\section{Gutiérrez Solana}

José Gutiérrez Solana es uno de los grandes pintores españoles de este siglo que mejor refleja las costumbres populares y religiosas de España. Su temática -que trata los bajos fondos de la sociedad española - hunde sus raíces en la pintura negra de Goya, pero el gusto por la escenografía de la muerte lo toma del acervo artístico del Renacimiento. Hacemos ahora un recorrido sumario, cronológico en la medida de lo posible, de su producción pictórica "religiosa", que comienza en 1905 con uno de los temas predilectos del pintor ${ }^{30}$. Se trata de Procesión en Toledo, impregnado del tenebrismo que caracteriza su arte. Ese mismo año, muy prolífico para el artista, volvió a pintar procesiones, una con el título Procesión de la Semana Santa, otra La Procesión de los Escapularios, el Cristo milagroso de Huesca y el Ermitaño ${ }^{31}$. Hacia 1910-1912 Gutiérrez Solana abordó un tema nuevo: El monje muerto, prueba inequívoca de su interés por trasladar al lienzo la tragedia de la muerte, o más precisamente de la muerte mística. El difunto yace en el féretro a los pies de un gran crucifijo flanqueado por dos filas de monjes ${ }^{32}$, quizá inspirado en la obra de Zurbarán titulada Los funerales de San Buenaventura. De 1912 data Disciplinantes ${ }^{33}$, tema que ya trató Goya. La Procesión en Castilla es obra del año $1912{ }^{34}$, pero introduce la variante que en esta ocasión la procesión avanza por el centro de la calle, entre apiñados devotos y miembros del clero. Esta disposición en el tema de procesión se repite en 1914, en Rogativas ${ }^{35}$.

${ }_{29}$ Gómez del Caso, Ignacio Zuloaga, 1870-1945, Gráficas Valdés 1990, pp. 190-191; E. Lafuente Ferrari, La vida y el arte de Ignacio Zuloaga, Madrid, 1950, lám. 43.

${ }^{30}$ L. Alonso Fernández, J. Solana. Estudio y catalogación de su obra, Madrid, 1985, p. 131, Rep. 75; L. Rodríguez Alcalde, Solana, Madrid, 1974, pp. 185-187; E. M. Aguilera, Solana, Barcelona, 1947, lám. XXII. Los artistas españoles de finales del siglo xix y de comienzos del xx se ocupan de representar en sus óleos aspectos parecidos de la religiosidad popular, como Constantin Meunier, La oración. Capilla de la plaza de Sevilla, 1982-1983. D. Regoyos, El mes de María en Bruselas, 1984; Después de la misa, 1884; Corpus de Fuenterrabia, 1888; Hijas de María, 1891; del mismo pintor, que en sus Diarios, dibujó 5 Cristos diferentes. Ramón Pichot, pintó en 1898 una Ofrenda; Pablo Uranga en 1905, Procesión de Elgueta (Varios, Paisaje y figura del 98, Torrejón de Ardoz 1997, pp. 108-112, 115, 124, 135, 182).

31 L. Alonso Fernández, Op. cit., 133, 16; 133, P 18, Rep. 76; p. 140, P 36; p. 141, P.37; respectivamente.

${ }^{32}$ L. Alonso Fernández, Op. cit., p. 144, P. 47, Rep. 77.

33 L. Alonso Fernández, Op. cit., p. 147, P. 52.

${ }^{34}$ L. Alonso Fernández, Op. cit., p. 148, P. 54.

35 L. Alonso Fernández, Op. cit., p. 149, P. 57. 
Entre 1917-1920 Solana realiza otras tres procesiones ${ }^{36}$, con variantes en la representación de los pasos en que aparece la figura de Cristo, pero siempre con las características del pintor, que con el contraste de colores claros y sombríos, y con los gestos de los personajes intervinientes sabe trasmitir perfectamente la sensación de sufrimiento. La imagen de la Virgen Dolorosa es novedad que se introduce en dos composiciones de 1917-1919, destacando la Procesión de Semana Santa en Cuenca ${ }^{37}$ (Fig. 8), con encapuchados vestidos de blanco, la Virgen con el Nazareno con un fondo de casas tomadas del natural.

Posteriormente, aunque en fecha no precisada, se repite el tema de la Dolorosa en una Procesión en Santander. De 1917 realiza una variante procesional de su ciudad natal, la Procesión. Salida de la catedral de Santander ${ }^{38}$, obra de bruscos contrastes de colores, en la que destaca la blancura del cuerpo de Cristo. Entre 1917 y 1921 realiza dos cuadros casi idénticos: Procesión, Zorral y piedras y La Dolorosa ${ }^{39}$, tema tratado por el artista en varias ocasiones. De 1927 es el Cristo de la Sangre, de 1920 (Fig. 9), posiblemente el mejor de los Cristos pintados por Solana; y al año siguiente hace un cuadro religioso con un grupo de santos de talla ${ }^{40}$ (Fig. 10), una Dolorosa con el hijo muerto, un Cristo, dos Vírgenes con el Niño Jesús, y Cristo. En 1930 realiza tres obras: Antes de la Procesión ${ }^{41}$, Procesión del Descendimiento ${ }^{42}$, y Procesión de la muerte ${ }^{43}$, y los años siguientes, 1939 y 1931, introduce dos temas relativos a la muerte, clásicos en el Renacimiento, el Triunfo de la Muerte -que repite en 1932, que se inspira en una obra de autor anónimo, fechado en 1445, del antiguo hospital de Palermo, y otro cuadro con el mismo nombre de P. Breughel el Viejo- y el Osario ${ }^{44}$. El Rapto de San Ignacio, 1931, es una de las pocas obras de Solana en la que el protagonista es un santo ${ }^{45}$.

El tema de la muerte y el dolor está presente siempre en la obra de Solana, incluso en obras menores, como ex libris, 1920, y en dibujos de pequeño formato preparatorio de obras mayores. De los últimos años (1942) es un dibujo a tinta y acuarela sobre pastel de una procesión de la Dolorosa debajo de un arco, acompañada del clero y de los devotos ${ }^{46}$. Solana no se interesó por los distintos episodios evangélicos que narran la vida pública de Jesús, como hace por ejemplo

36 L. Alonso Fernández, Op. cit., p. 160, P. 19; p. 160, P. 80; y p. 161, P. 82 (la llamada Procesión de Toro).

37 L. Alonso Fernández, Op. cit., p. 159, P. 78. Esta procesión se repite hacia el año 1918, con figuras diferentes: Cuenca al fondo con las casas sobre una colina cortada a pico, y dos pasos en el centro, el Crucificado entre dos personas y un Nazareno (L. Alonso Fernández, Op. cit., p. 169, P. 101, Rep. 79); E. M. Aguilera, Op. cit., láms. XLIII- XLIV.

38 L. Alonso Fernández, Op. cit., p. 166, P. 93. Sobre las procesiones en Santander, ver F. Gutiérrez Díaz, Semana Santa en Santander: cinco siglos de historia. Antiguas y modernas procesiones, Santander 1993; y los escritos del propio J. Gutiérez Solana, La España negra en Cantabria, Santander, 1987. Sobre la obra escrita y pictórica de Solana, ver: J. L. Barrio Garay, José Gutiérrez Solana: Paintings and writings, Lewisburg, 1978.

39 L. Alonso Fernández, Op. cit., p. 166, P. 93; y p. 167, P. 94, Rep. 78.

40 L. Alonso Fernández, Op. cit., p. 205, P. 177.

41 L. Alonso Fernández, Op. cit., p. 213, P. 196.

42 L. Alonso Fernández, Op. cit., p. 215, P. 200.

43 L. Alonso Fernández, Op. cit., p. 215, P. 201, Rep. 59. Una obra clave de la temática de la muerte se titula El espejo de la muerte, fechada en 1929 (L. Alonso Fernández, Op. cit., pp. 84-85), que como escribió J. de la Puente en 1972, "es una obra en la que el espacio mismo de Solana cobra evidente carácter simbolista, mágico, y quién sabe si hasta surrealista. La vida-femineidad y la muerte se yuxtaponen".

44 L. Alonso Fernández, Op. cit., p. 201, P. 212. El cuadro de H. Baldung Grien, en A. Stange, Op. cit, lám. 126. La representación de la muerte, sobre un caballo, en el centro del cuadro titulado La Guerra, de Solana, admite la comparación con La muerte coronada de Durero. (fig. 11.)

45 L. Alonso Fernández, Op. cit., p. 221, P. 213.

46 L. Alonso Fernández, Op. cit., p. 337, D. 167. Solana se interesó también expresar el sentimiento de piedad individual en un par de aguafuertes, de 1920, titulados Mujer con rosario y Mujer del reclinatorio (L. Alonso Fernández, Op. cit., p. 339). Solana por lo general no prestó interés a los interiores de las iglesias. Una excepción es la Capilla de los santos mártires Emeterio y Celedonio, patronos de Santander, obra de 1915 (L. Alonso Fernández, Op. cit., p. 285, D. 25). 

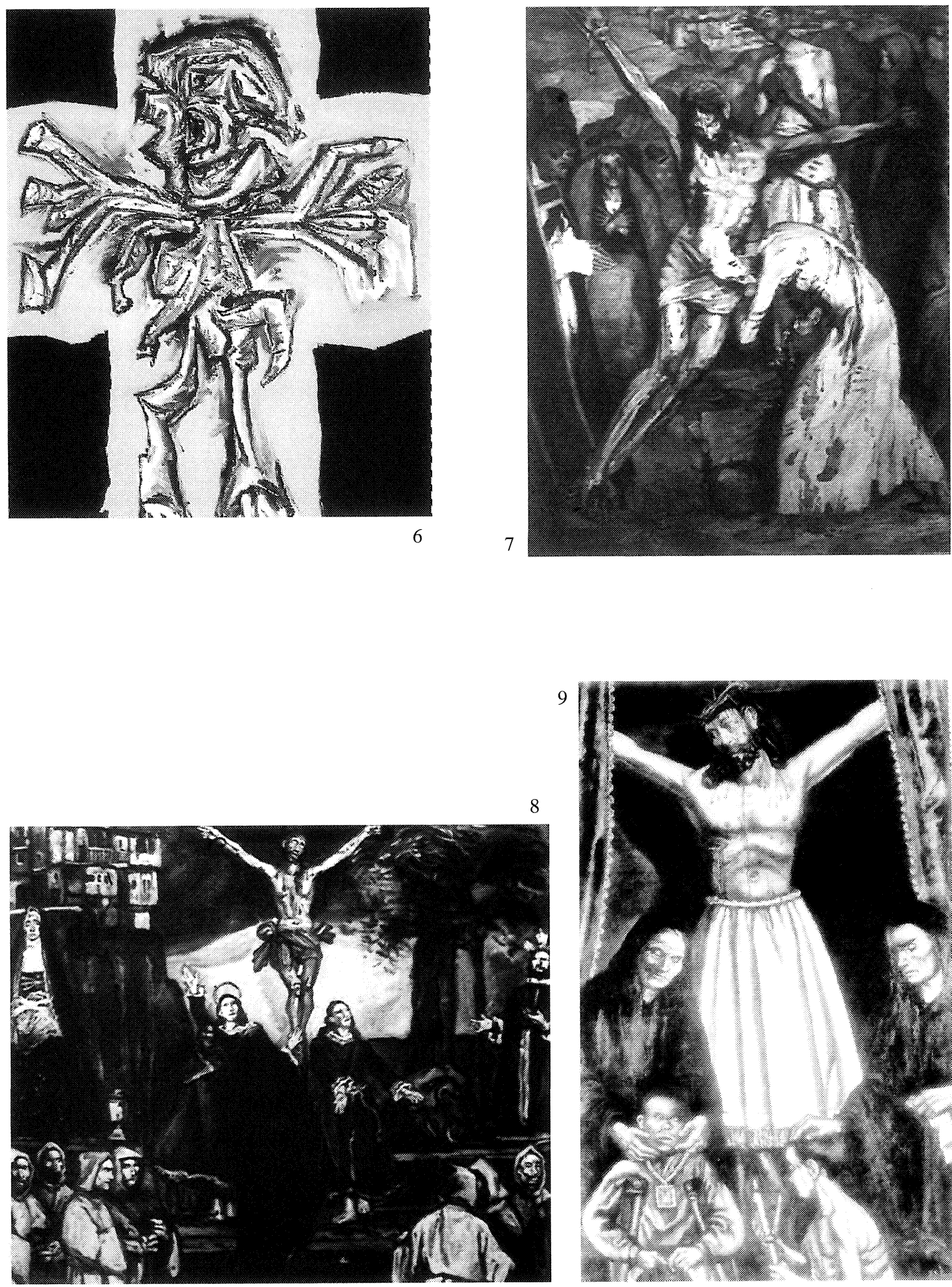

Fig. 6. Antonio Saura, Crucifixión, 1959. Madrid, Centro de Arte Reina Sofía.

Fig. 7. Zuloaga, Flagelantes. Nueva York, Museo de la Hispanic Society.

Fig. 8. Gutiérrez Solana, Procesión en Cuenca, 1918. Madrid, Colección particular.

Fig. 9. Gutiérrez Solana, El Cristo de la sangre, 1920. París, Museo de Escuelas Extranjeras. 
el escultor Juan de Ávalos en el Valle de los Caídos 47, ni representar Cristos yacentes, tan frecuentes en el arte español ${ }^{48}$, ni cuadros de tema bíblico. Sobre la obra de Solana trataremos extensamente en otro trabajo.

Dalí

Dalí mostró gran interés por los temas religiosos en una etapa ya avanzada de su producción artística, cuando ya había alcanzado fama internacional. El pintor español inicia tal temática con un motivo que tuvo gran aceptación en el arte: el apocalíptico Jinete de la muerte (Fig. 12). En esa obra se manifiesta ya la extraordinaria calidad del dibujo de Dalí, el dominio de los colores, y es muestra de su desbordante imaginación. El paisaje rocoso y la negrura de las nubes complementan perfectamente la escena principal. La Muerte es tema frecuente en la obra daliniana ${ }^{49}$, al igual que en Gutiérrez Solana. De 1937 datan dos temas bíblicos. Uno se titula Salomé, y otro Herodías ${ }^{50}$, típicamente surrealistas. En 1945 Dalí realizó uno de sus grandes cuadros religiosos, titulado La resurrección de la carne (Fig. 13), fruto de la fantasía inigualable de este pintor, que demuestra a través de su producción un sentimiento de pavor ante la muerte. La resurrección, por tanto, es una especie de consuelo. Escribió el artista: “No transcurre ni un sólo minuto de mi vida sin que el sublime espectro católico, apostólico, y romano de la muerte no me acompañe hasta en las más sutiles y caprichosas fantasías" ${ }^{51}$.

A partir de 1946 Dalí se convierte al misticismo. Comienza su nueva etapa artística con una composición frecuente en el Renacimiento, Las tentaciones de San Antonio (Fig. 14) ${ }^{52}$. La vida de este santo es conocida por una obra magistral de Atanasio, la Vida de Antonio. El santo se retiró hacia el año 270 al desierto egipcio para dedicarse a la vida ascética huyendo de los pecados de la carne. La tentaciones que sufre San Antonio en este sentido está magníficamente reflejada en la obra de Dalí, que coloca dos figuras de mujeres desnudas sobre unos elefantes de alargadas y desproporcionadas patas, situándolas entre el cielo y la tierra. Los animales simbolizan también la levitación presente en las "pinturas místicas corpusculares». San Antonio soporta seis tentaciones sucesivas. El caballo encabritado es símbolo del poder y, por sus formas voluptuosas, de la lujuria, representada en una mujer de voluminosos senos y de cuerpo carnoso. El tercer elefante lleva sobre sus espaldas una copa del obelisco de Bernini; el cuarto, el cuerpo de una dama desnuda dentro de un edificio; y el último una torre fálica. Dalí presentó esta obra a

\footnotetext{
47 Sobre la obra de Ávalos es fundamental el trabajo de J. Trenas, Juan de Ávalos, 1911-Valencia, 1978. Ávalos tiene numerosas esculturas con el tema de la Piedad y Cristo yaciendo en sus brazos: Piedad profana (dos), en bronce y barro (J. Trenas, Op. cit., láms. 74 y 75); Piedad, relieve en piedra (ibid. lám. 80); Piedad, de Mérida, en piedra (ibid. lám. 109); Estudio para la primera Piedad de Cuelgamuros y Primera Piedad de Cuelgamuros (ibid. láms. 110 y 112); Bocetos de Piedad, en bronce y barro (ibid. láms. 114-117); y Modelación en barro y Obra definitiva en piedra de la Piedad del Valle (ibid. láms. 119 y 120). Sobre el escultor ver ahora: M. Bazán, Ávalos, Badajoz, 1996.

48 J. J. Martín González, El escultor Gregorio Fernández, Madrid 1980, pp. 189-201 y láms. 155-172. Que se completa con las siguientes obras: J. Urrea, "A propósito de los yacentes de Fernández» BSAA 1972, pp. 543 ss.; A. Ramos Notario, Escultura barroca española, Gregorio Fernández y su época, Madrid, 1987, pp. 193-210 sobre los yacentes castellanos; y A. Igual Úbeda, Cristos yacentes en las iglesias valencianas, Valencia 1964.

49 R. Descharnes-G. Néret, Dali 1904-1989. La obra pictórica, Colonia, 1993, pp. 240-241, figs. 546-547; R. N. Descharnes, Salvador Dali, París, 1993, p. 167.

50 R. Descharnes-G. Néret, Op. cit., pp. 294-295, figs. 653-654.

51 R. Descharnes-G. Néret, Op. cit. pp. 387, 395, fig. 871; R. N. Descharnes, Op. cit., p. 234; De Draeger, Dalí, Barcelona, 1968, fig. 67. Éste es un tema de larga tradición tratado por Luca Signorelli en un fresco de Orvieto en 1499 (B. Beimling, "Malerei der Frührenaissance in Florenz und Mittelitalien», en R. Toman, Die Kunst der italienischen Renaissance, Colonia, 1994, pp. 302-303).

52 R. Descharnes-G. Néret, Op. cit., II, pp. 406-407, fig. 906. El tema es realizado por El Bosco (se le atribuían cinco cuadros en 1652), P. Huys (dos, de 1547 y 1577), Jean Mandyn, P. Breughel el Viejo, Corneille van Dalem, M. Ernst, etc.
} 


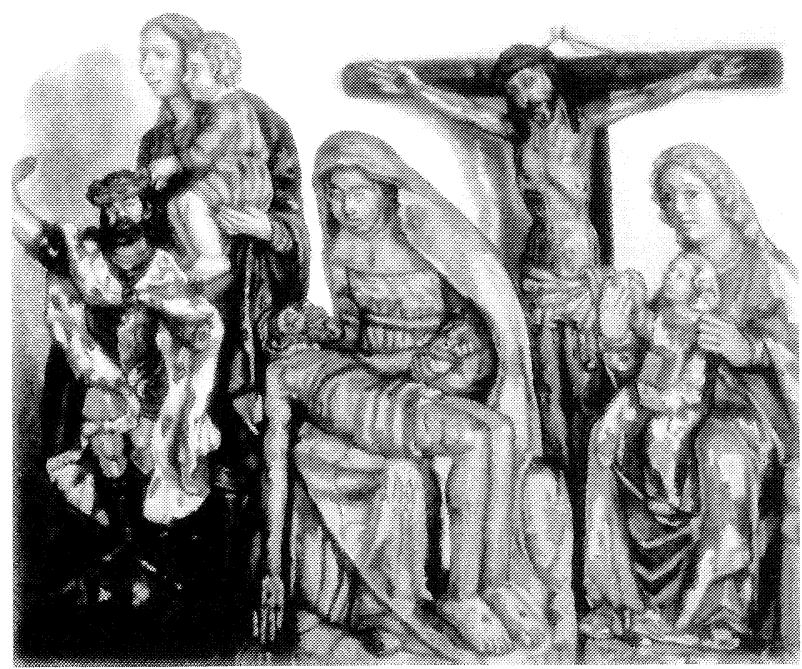

10

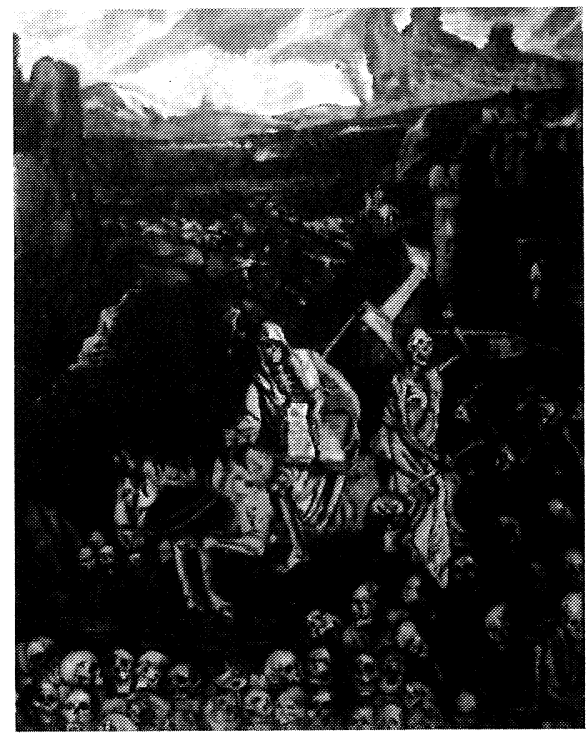

11

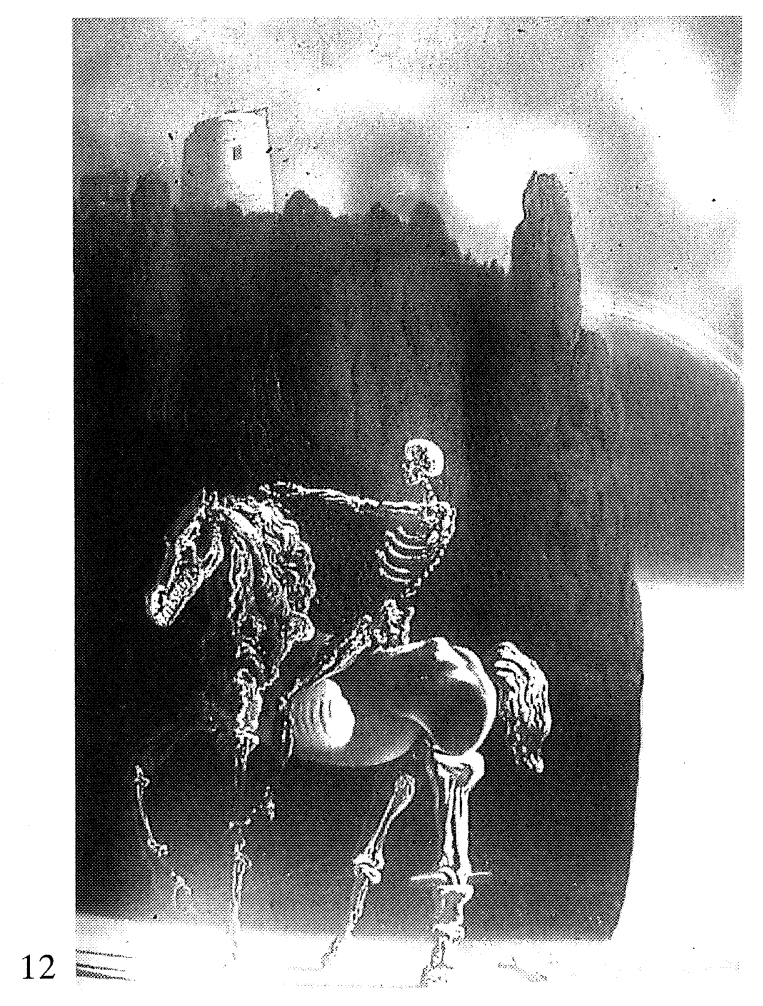

Fig. 10. Gutiérrez Solana, Santos de talla, 1928. Colección F. Espildosa.

Fig. 11. Gutiérrez Solana, La guerra, 1920. Madrid, Colección particular. 1905-1907.

Fig. 12. S. Dalí, Jinete de la muerte, 1935. París, Colección André-François Petit. 
un concurso al que concurrieron once artistas con cuadros de la misma temática, y fue elegido el mejor, y el único «que reflejó los miedos y los deseos de la épica de las gárgolas». A partir de este momento el artista se centra en su producción espiritualística porque «afirmó, por todo lo alto, que el cielo se encuentra en el centro del pecho del hombre que tiene fe, porque mi mística no es solamente religiosa». A este momento místico pertenece la Madonna de Port Lligat ${ }^{53}$, de 1949, con la imagen de la Virgen recogida en oración dentro de un arco descompuesto, y con el Niño en su interior en un sagrario (Fig. 15).

Una tercera obra, con variantes, se data al año siguiente, en $1950{ }^{54}$. Dalí escribió por entonces en su Vida Secreta: «en este momento todavía no tengo fe y temo que moriré sin cielo»; y en 1952: «en esta época de decadencia de la pintura religiosa... el genio sin fe es más valioso que el creyente desprovisto de genio... Estamos convencidos de que los ateos, y aun los miembros del Partido Comunista (como por ejemplo Picasso), los artistas geniales estarían en condiciones, si así lo desearan, de crear grandes obras religiosas... Naturalmente, también veré el peligro demoníaco que amenaza el arte religioso si se sirve de los servicios de artistas ateos. Lo ideal sería que el arte religioso fuera ejecutado, como ocurría en época del divino Renacimiento, por artistas de genio tan profundo como su fe, como fue el caso, por ejemplo, de Zurbarán, el Greco, Leonardo da Vinci, Rafael... Es innegable que el arte moderno representa en sí mismo las consecuencias últimas y fatales del materialismo... Los artistas llamados abstractos son fundamentalmente artistas que no creen en nada... Estoy convencido del próximo fin del materialismo... Veo venir un fabuloso renacimiento de la pintura moderna, que por reacción contra el materialismo actual será nuevamente figurativo y representativo de una nueva cosmogonía religiosa».

Este texto es muy valioso por proceder de uno de los grandes colosos del arte moderno.

En la corriente mística de Dalí la pintura más conocida es el Cristo de San Juan de la Cruz ${ }^{55}$ (Fig. 16), obra de 1951, inspirado en un dibujo del místico español en un momento de éxtasis; realizado en la misma técnica que la Cesta de panes ${ }^{56}$. La finalidad de Dalí al pintar este cuadro, al contrario de los pintores modernos al interpretar a Cristo en el sentido expresionista y contorsionante, provocando la emoción por medio de la fealdad, era pintar un Cristo bello como el mismo dios, al cual encarna. A esta misma concepción mística, y a ese momento artístico, pertenecen otras obras como la Cruz aritmosófica, 1952; Cruz nuclear, 1952, 1953; La Cruz del ángel, 1960; y Assumpta corpuscuparia lapislazurina, 1952; Crucifixión (dos); La Asunción antiprotónica, $1956{ }^{57}$. Esta etapa se cierra con una de las obras más geniales de Dalí, por los matices de sus colores: $L a$ Øltima Cena, $1955^{58}$, inspirada en el cuadro homónimo de Leonardo da Vinci, aunque interpretado libremente. La composición tuvo gran aceptación en el Renacimiento, como Dierik Bouts, 1464-1467; Andrea del Castagno, 1447-1449; J. Huguet, 1500; Tintoretto, 1592-1594; etc.

53 R. Descharnes-G. Néret, Op. cit., p. 423, 426-427, figs. 939-940. Diversos artistas del Renacimiento realizan cuadros de San Jerónimo, A. Stange, Op. cit., láms. 132, 137.

${ }_{54}$ R. Descharnes-G. Néret, Op. cit., p. 443, fig. 981.

${ }_{55}$ R. Descharnes-G. Néret, Op. cit., pp. 436, 441, 451, fig. 1003; R. N. Descharnes: Op. cit., pp. 242-253; De Draeger, Op. cit., p. 111.

56 R. Descharnes-G. Néret, Op. cit., p. 386, fig. 870.

57 R. Descharnes-G. Néret, Op. cit., pp. 452-454, 466, 467, 486., figs. 1004, 1006, 1008, 1009, 1011, 1012, 1040, 1043, 1097. De Draeger, Op. cit., fig. 105; R. N. Descharnes, Op. cit., p. 274. Para los cuadros del Renacimiento con la Última Cena: M. Beimling, Op. cit., p. 266; A. Ranchi, "Malerei der Reinaissance in Venedig und Norditalien», en R. Toman, Op. cit., p. 409. En 1978 pintó Dalí El Cristo de Gala, que es el mismo Cristo de cuadros anteriores, pero cambiando de postura del cuerpo, visto de arriba abajo (R. Descharnes-G. Néret, Op. cit., p. 667, figs. 1485-1486). El Cristo más original de Dalí, que rompe todos los esquemas artísticos es el Cristo de los deshechos, obra del año 1969, utilizando material de derribo, como tubos de cañerías, palos de una barca por cuerpo, tirada en el suelo en un paisaje agreste, en el olivar de Por Lligat (R. Descharnes-G. Néret, Op. cit., p. 607, fig. 1360).

58 R. Descharnes-G. Néret, Op. cit., pp. 488-489, fig. 1098; R. N. Descharnes, Op. cit., p. 257. La obra pictórica religiosa de Dalí, hasta esta fecha, fue estudiada por J. V. L. Brans, «La pintura religiosa de Dalí» Goya 21, 1957, pp. 156-164. 
13
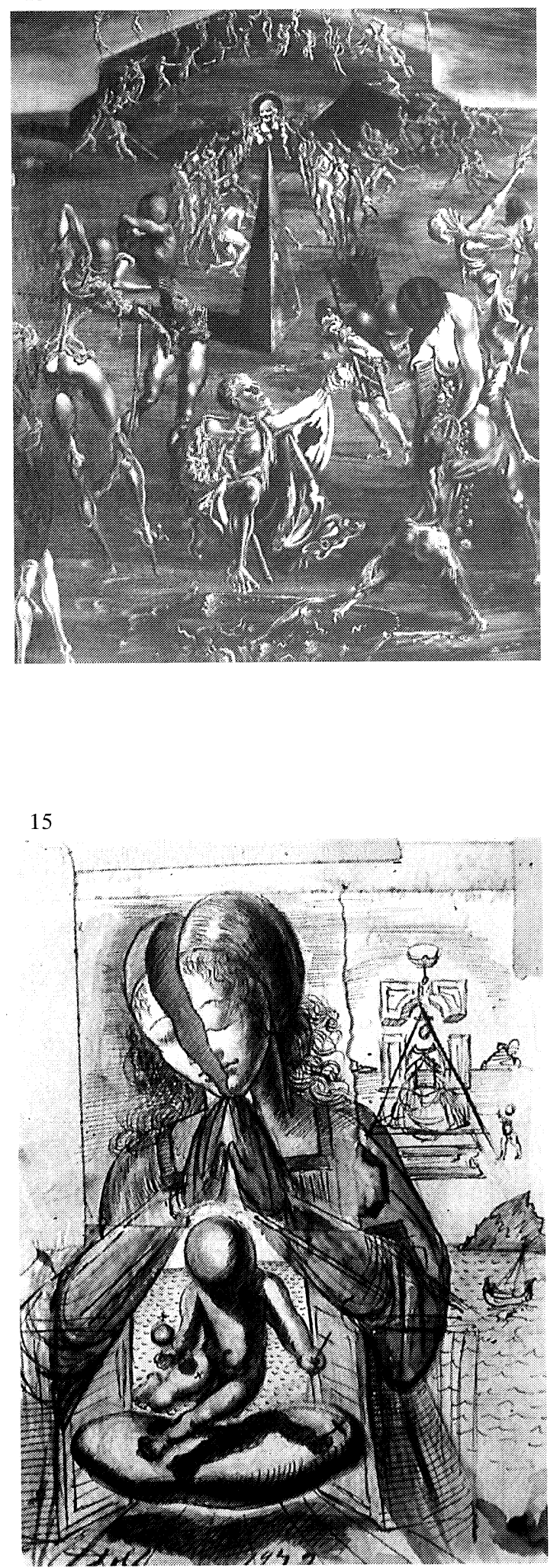

4

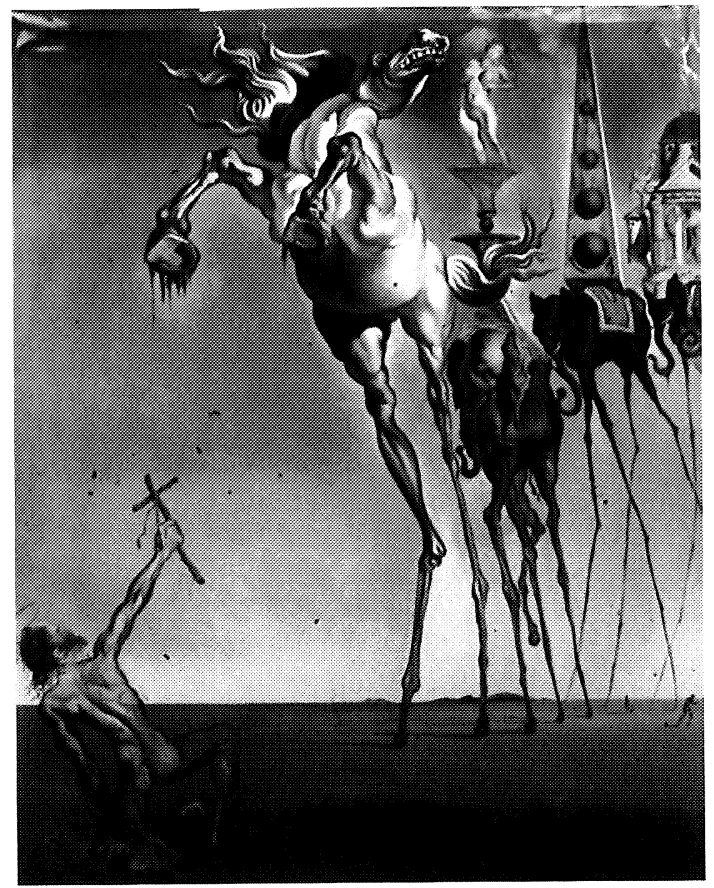

16

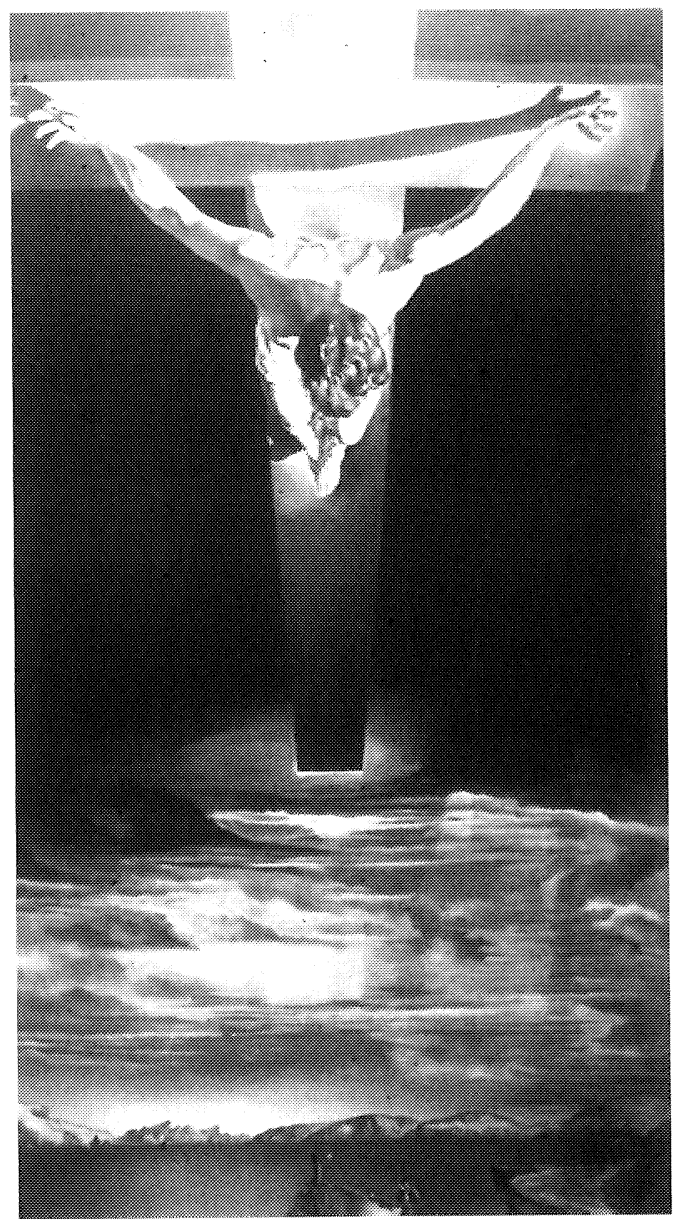

Fig. 13. S. Dalí, Resurrección de la carne, 1940-1945. Colección Bruno Pagliai.

Fig. 14. S. Dalí, Las tentaciones de San Antonio, 1946. Bruselas, Musée Royal des Beaux-Arts de Bélgica. Fig. 15. S. Dalí, Estudio para "La Madonna de Port Lligat», 1949. Figueras, Fundación Gala-Salvador Dalí. Fig. 16. S. Dalí, Cristo de San Juan de la Cruz, 1951. Glasgow, The Glasgow Art Gallery. 
La actividad artística de Dalí en estos años es frenética. Los temas religiosos le siguen obsesionando, y prácticamente no los abandonará ya hasta el final de sus días. Son de temática variada. Así, en 1957 pinta, en tamaño descomunal, un Santiago el Grande ${ }^{59}$ (Fig. 17), en variadas tonalidades azules, dentro de los nervios de la bóveda celeste, montando un caballo encabritado que dirige su mirada, con el brazo izquierdo extendido, hacia el Cristo del que surgen rayos. Entre los años 1958-1960 realizó la Madona cósmica, 1958; La Asunción, del mismo año; Cristo del guijarro, 1959 La Virgen de Guadalupe, 1959 (Fig. 18); obra de gran originalidad, pues muestra un manto repleto de ángeles, seres muy querido y representados por Dalí; La sirvienta de los discípulos de Emaús, 1960; La Trinidad, Santa Ana y el Niño, 1960; Escena religiosa corpuscular, 1958; Santa Ana y San Juan, 1960; San Salvador y Antonio Gaudí, 1960; Pietá en el Apocalipsis de San Juan, 1960 (Fig. 19); Bomba del Apocalipsis, 1959; Cubierta del Apocalipsis, del mismo año; y Cristo en el Apocalipsis, de 1958 y 1960; y El Concilio Ecuménico, $1960{ }^{60}$. Escenas del Apocalipsis no son muy frecuentes en la pintura española. Una excepción es el Quinto sello del Apocalipsis del Greco, hacia 1608-1614.

Esos años son muestra de la extraordinaria capacidad de trabajo, de una fantasía y una originalidad sin límites en el tratamiento de los temas, fantasía que en el caso de la pintura religiosa nunca son irreverentes. El genio único de Dalí rompe con todos los ismos que caracterizan el arte moderno anterior a él. Quiere ser el mejor pintor, el más original, y mejor dominador del dibujo y de los colores; pone su empeño en ello. Proclama en alto su deseo de barrer el arte moderno. Algunos de los cuadros citados son cumbres en la trayectoria de su arte. La lista de cuadros religiosos se puede hacer extensivo a otros títulos: Basilica de San Pedro, Explosión de fe cristiana en el centro de una catedral, 1960-1979, que es un estudio de la arquitectura interior de un templo; y Retrato de San Jerónimo, $1960{ }^{61}$, santo que tuvo mucha aceptación entre los artistas del Renacimiento. Basta recordar el San Jerónimo del Maestro del Rhin, 1480; una punta seca de Durero titulada San Jerónimo junto a un sauce, 1512, y un grabado a buril de 1514 con el título San Jerónimo en su celda; el San Jerónimo del Bosco, 1500, el de Hans Burgkmaier, Jean van Hemessen, M. van Reymerswale y J. Patinir. En la pintura española San Jerónimo fue también tema frecuente. Aparece en Las tentaciones y La flagelación de Zurbarán, y en seis cuadros del Greco entre los años 1595 y 1614.

Algunas madonas de Dalí están dentro de las normas tradicionales de representar a la Virgen y el Niño ${ }^{62}$. Por contra, El Sagrado Corazón de Jesús, 1962, es de gran originalidad, y no responde a los cánones habituales, ni en la forma ni en la postura ladeada del cuerpo, ni en el corazón ni en el brazo derecho con una cruz ${ }^{63}$.

Dalí se interesó por la figura de San Juan, representado una vez de frente, otra de perfil, con fondos parecidos ${ }^{64}$. Las escenas del Apocalipsis eran caldo de cultivo propicio a la desbordante imaginación daliniana. De 1970 y 1971 data el cuadro Los Caballeros del Apocalipsis, de corte impresionista, con colores oscuros y rojos; y Segunda llegada de Cristo, a caballo, llegando desde el cielo, figura de estilo clásico, y un par de dragones sobre fondo claro ${ }^{65}$.

59 R. Descharnes-G. Néret, Op. cit., p. 496, fig. 1113; R. N. Descharnes: Op. cit., p. 280. El tema de la Resurrección de la carne es rarísimo en artistas modernos. Una excepción en M. Beckmann, 1909 (K. D. Gleisberg, Max Beckmann, Frankfurt, 1991, pp. 64-65).

60 R. Descharnes-G. Néret, Op. cit., pp. 512-513, 523, 527, figs. 1147-1156, 1162-1165. Con motivo de sus obras sobre el Apocalipsis de San Juan. Dalí realizó una acuarela y pluma del busto de San Juan, que expresa magníficamente a un visionario (R. Descharnes-G. Néret, Op. cit., p. 491, fig. 1102).

61 R. Descharnes-G. Néret, Op. cit., p. 519, figs. 1160-1161. Los cuadros de San Jerónimo mencionados en el texto: A. Stange, Op. cit., pp. 132, 136 .

62 R. Descharnes-G. Néret, Op. cit., pp. 546-547, figs. 1217, 1220.

63 R. Descharnes-G. Néret, Op. cit., pp. 546-547, figs. 1217-1218, 1220.

64 R. Descharnes-G. Néret, Op. cit., pp. 553, 562, figs. 1232, 1255.

65 R. Descharnes-G. Néret, Op. cit., pp. 596-597, figs. 1331, 1335. 
Es necesario recordar otras tres obras de tema religioso, de la última etapa del genial artista español: Pietá, 1982 (Fig. 20), inspirada en la escultura del mismo nombre de Miguel Angel, con figuras de tono gris sobre fondo azul y amarillo ${ }^{66}$. Una segunda Pietá es obra de $1983{ }^{67}$. Una tercera, realizada en 1986, está influenciada por la Piedad de Palestrina de Miguel Angel ${ }^{68}$. La Pietá es una composición muy propia del Renacimiento como lo indican las obra de pintores como E. Guarton, hacia 1460, y de Tiziano, 1575-1576; y entre los artistas españoles hay tres cuadros del Greco con este tema, dos entre los años 1570-1574, y la tercera en torno al 15801582. Dalí se inspira en la Pietá más famosa y perfecta, la citada de Miguel Angel en el Vaticano.

Dalí realiza un San Sebastián en 1983, con excelente estudio anatómico, en pie, sostenido por unas horquillas ${ }^{69}$. Este santo es de gran tradición en la pintura italiana (por ejemplo el San Sebastián de Guido Reni, en el Prado), o el del Greco, pintado hacia 1577-1578. Dalí, unos años antes, en 1982, había pintado Mártir, que es un cuerpo humano retorcido por el dolor, obra inspirada en los sufrimientos del propio artista durante una enfermedad. El sufrimiento está perfectamente retratado en el rostro. Los rayos del fondo realzan la sensación de dolor ${ }^{70}$. Dalí también decoró el Padre Nuestro ${ }^{71}$.

\section{Temas religiosos en joyas de Dalí}

El artista español realizó varios diseños de cruces en joyas, que son de gran originalidad: Cruz de lapislázuli, en oro, lapislázuli, brillantes y rubíes. Según Dalí: «Rayos de brillantes representan la luz de Cristo. Su sangre. El árbol, de oro grabado, va montado sobre cubos de. lapislázuli. El conjunto significa, en color, forma y materia, la Energía y Poder de Cristo" ${ }^{72}$; la Cruz de cubos de oro ${ }^{73}$, cubos que forman una cruz sobre una explosión solar de brillantes "que simbolizan la Pasión y el Sacrificio de Cristo" ${ }^{74}$; Veritas vincit, obra de oro esculpido, perlas, rubíes, brillantes y lapislázuli ${ }^{75}$. «Entre mares de lapislázuli -dice el artista- y rayos de diamantes, reposa una cruz de perlas junto a otra de rubíes en una tierra dorada. La Resurrección y la Vida». La Luz de Cristo es una joya realizada en oro esculpido y brillantes, "por la luz de Cristo, y rubíes por Su Sangre. Los brillantes estallan y destruyen la Cruz, para significar la fe que ningún mal puede resistir el Poder de Cristo" ${ }^{76}$.

La más ambiciosa de las joyas de Dalí es La Cruz del ángel 77, de 1960, hecha de brillantes, platino, oro, lapislázuli de Rusia, coral oscuro de China, topacio purísimo de Brasil y sulfato de zinc cristalizado de Africa. «Representa el tratado de la existencia; la transformación gradual desde el mismo mineral hasta el ángel. Las doce espinas de la base simbolizan los doce apóstoles, los doce meses del año, los doce signos del zodíaco, las doce tribus de Israel, las doce puertas de la Nueva Jerusalén, y los doce cimientos de la Ciudad Sagrada. Las espinas representan el

66 R. Descharnes-G. Néret, Op. cit., p. 698, fig. 1565.

67 R. Descharnes-G. Néret, Op. cit., p. 718, fig. 1608.

68 R. Descharnes-G. Néret, Op. cit., p. 708, fig. 1586.

69 R. Descharnes-G. Néret, Op. cit., pp. 709-710, fig. 1589.

70 R. Descharnes-G. Néret, Op. cit., p. 713, fig. 1600.

71 M. De Acevedo, Pater Noster, Madrid, 1992.

72 Dali. Su arte en Joyas. Colección The Owen Cheatham Foundation, Madrid, 1973, p. 13, lám. 3. Sobre este tema ver el reciente trabajo de T. Jiménez, "Joyas de artistas: Joyas de Dalí", Espacio, Tiempo y Forma, Serie VII, H. ${ }^{a}$ del Arte, 9 , 1996, pp. 343-373, espec. pp. 362-373 y figs. 12 (Medalla de la Paz, 1963) y 17 (Collar del árbol de la Vida 1949)

73 Dali. Su arte en Joyas, p. 14, lám. 22.

74 Dali. Su arte en Joyas, p. 15, lám. 27.

75 Dali. Su arte en Joyas, p. 16, lám. 26.

76 Dali. Su arte en Joyas, p. 16, lám. 27.

77 Dali. Su arte en Joyas, p. 16, lám. 29. 

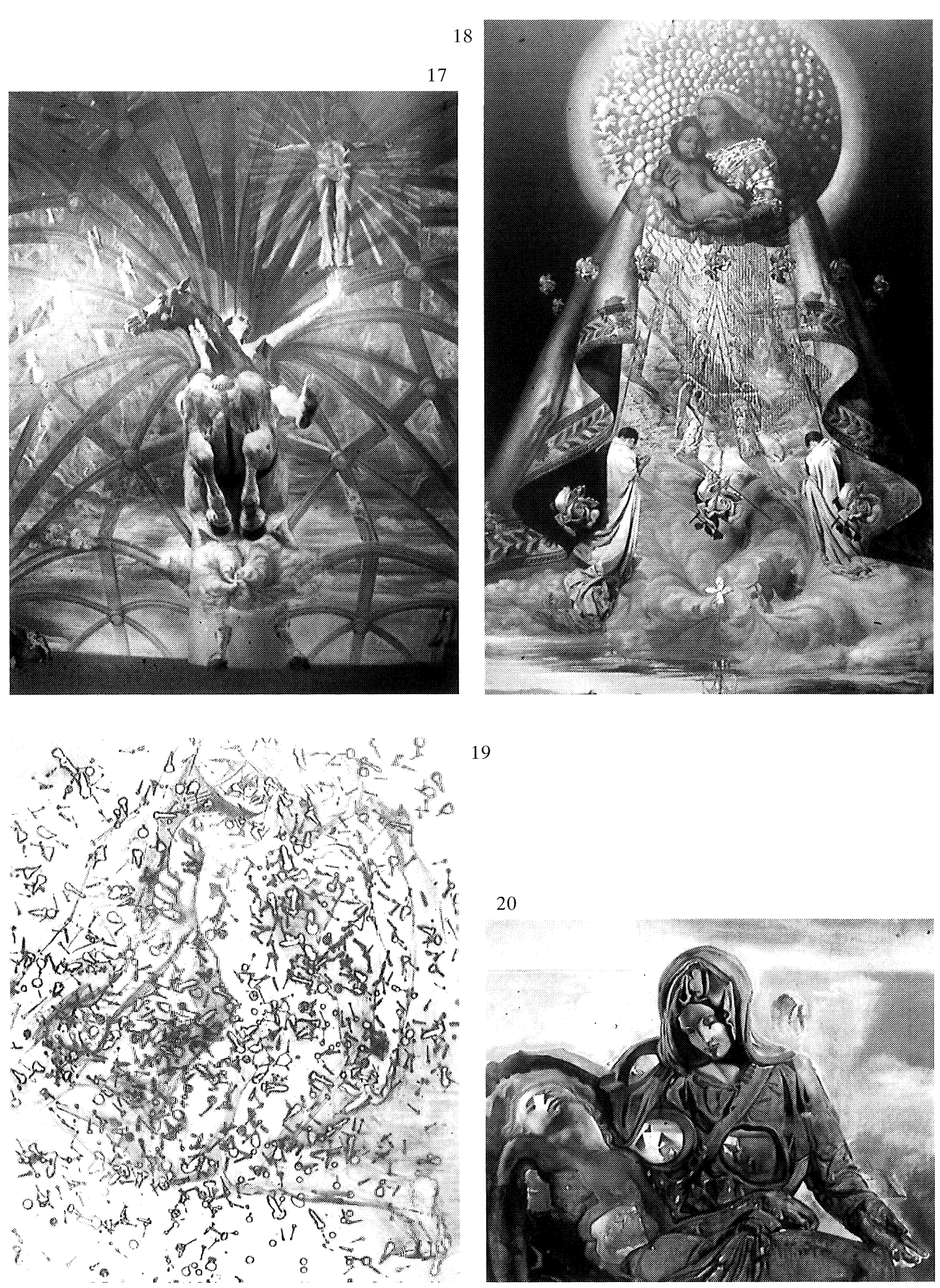

19

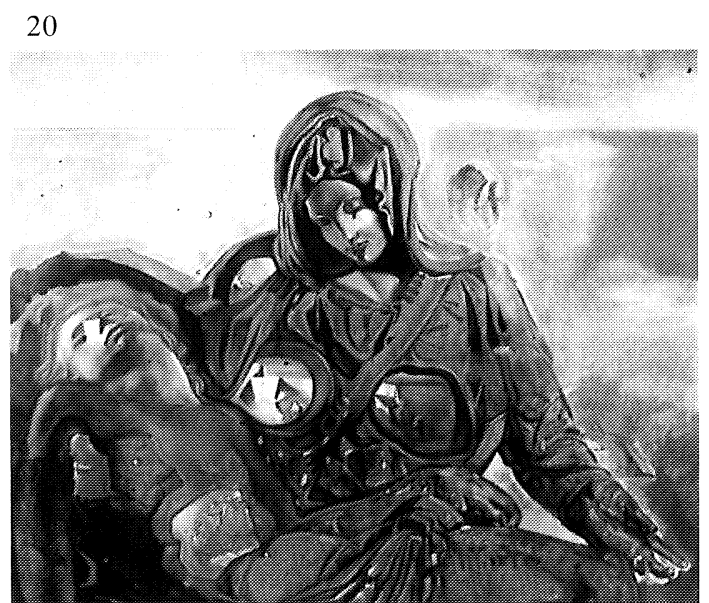

Fig. 17. S. Dalí, Santiago el Grande, 1957. Fredericton, Beaverbrook Art Gallery.

Fig. 18. S. Dalí, La Virgen de Guadalupe, 1959. Propiedad particular.

Fig. 19. S. Dalí, Piedad en el Apocalipsis de San Juan, 1960. Propiedad particular.

Fig. 20. S. Dalí, Piedad, 1982. Figueras, Fundación Gala-Salvador Dalí. 
mundo animal. El globo de lapislázuli simboliza el mundo mineral, y el coral el mundo de los plantas; y la Cruz el ser humano y el espiritual». El topacio pesa 1,687 kilates. Representa la Puerta del Tabernáculo y el Pórtico de los Cielos. "Con la puerta cerrada se ve la Sangre de Cristo a través de la piedra preciosa. Cuando la puerta de topacio está abierta, se ve el Cuerpo de Cristo, de oro virgen, pintado por Dalí con aceite y ámbar líquido, que es muchísimo más precioso que el esmalte». La escultura, según Dalí, «se ha construido sobre la Matemática del número doce». El movimiento de las espinas de brillantes y platino «muestran el ritmo cósmico de los erizos de mar moviéndose en la profundidad del subconsciente humano, con los abismos del mar». El interés por trabajar cruces es antiguo en Dalí. De 1952 son dos óleos sobre lienzo: la Cruz aritmosófica y la Cruz nuclear ${ }^{78}$.

Estos tres grandes artistas españoles han sabido expresar con su arte los sentimientos religiosos del hombre del siglo xx. Algunos artistas, como Picasso, Saura, y algún otro, utilizan el tema de la Crucifixión como paradigma de la brutalidad irracional de este siglo, del mismo modo que estos y otros artistas utilizan la mitología clásica para expresar, en el lenguaje artístico de nuestros días, los conflictos humanos que son similares en la Antigüedad y en los tiempos actuales ${ }^{79} . »$

\footnotetext{
78 R. Descharnes-G. Néret, Op. cit., p. 452, figs. 1004- 1006.

79 A este tema hemos dedicado varios trabajos: J. M. Blázquez, "Temas del mundo clásico en el arte del s. XX» Revista de la Universidad Complutense, XXI, 23, 1972, pp. 1-21; Id.: "El mundo clásico en Picasso" Discursos y ponencias del IV Congreso Español de Estudios Clásicos, Madrid, 1973, pp. 141-155; Id.: "Temas del mundo clásico en las pinturas de Kokoschka y Braque» Miscelánea de Arte, Madrid, 1982, pp. 269-274; Id.: "Mujeres de la mitología clásica en el arte español del siglo xx» La mujer en el arte español, Madrid, 1997, pp. 571-581; Id.: “El mundo clásico en Dalí», Goya (en prensa); Id.: "El mundo clásico en M. Beckmann» Anales de Historia del Arte (en prensa); J. M. Blázquez y M. P. García Gelabert, Temas del mundo clásico en el arte moderno español, Madrid, 1993, pp. 403-415.
} 